International Journal of Trend in Scientific Research and Development (IJTSRD)

Volume: 3 | Issue: 3 | Mar-Apr 2019 Available Online: www.ijtsrd.com e-ISSN: 2456 - 6470

\title{
The Ability of Raman Spectroscopy to Detect Surface Water Pollution in Northern Sudan
}

\author{
Sufyan Sharafedin Mohammed1, A. M. Awadelgied ${ }^{2}$, \\ Sohad saad El Wakeel ${ }^{3}$, Ahmed Abubaker Mohamed ${ }^{3}$ \\ ${ }^{1}$ Ph.D Student, ${ }^{2}$ Professor, ${ }^{3}$ Assistant Professor \\ ${ }^{2}$ Karary University, Omdurman, Sudan, North Africa \\ 1,3Sudan University of Science and Technology, Institute of laser. Sudan, North Africa
}

\begin{abstract}
How to cite this paper: Sufyan Sharafedin Mohammed | A. M. Awadelgied | Sohad saad El Wakeel | Ahmed Abubaker Mohamed "The Ability of Raman Spectroscopy to Detect Surface Water Pollution in Northern Sudan" Published in International Journal of Trend in Scientific Research and Development (ijtsrd), ISSN: 24566470, Volume-3 | Issue-3, April 2019, pp.1805-1811, URL: https://www.ijtsrd. com/papers/ijtsrd2 2906.pdf

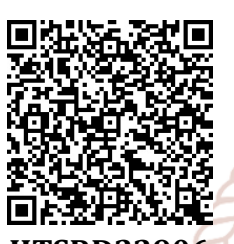
IITSRD22906
\end{abstract}

Copyright (C) 2019 by author(s) and International Journal of Trend in Scientific Research and Development Journal. This is an

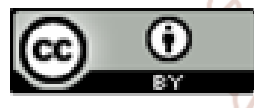
Open Access article distributed under the terms of the Creative Commons Attribution License (CC BY 4.0) (http://creativecommons.org/licenses/ by/4.0)

\section{INTRODUCTION}

Clean water is so basic to human life that water droplets, bubbling brooks, and waterfalls are enduring symbols of the life force. Obtaining an adequate supply of clean water has likely always been a challenge for much of humanity [1]. Despite the scientific and technological advancements of the modern society and, ironically, sometimes because of them, clean water is becoming an increasingly scarce and coveted resource. From these considerations, one has that water security is now a critical environmental issue that touches the life of every human being [2].

The increasing world population with growing industrial demands has led to a situation where protection of the environment has become a major issue and a crucial factor for several industrial processes, which will have to meet the requirements of the sustainable development.

\section{Theoretical Basis of Raman Spectroscopy}

Raman Spectroscopy effect was discovered by Indian physicists C.V. Raman in 1928 but only instrumental developments from 1980s brought about big progress of
Raman techniques. Although Raman Spectroscopy process is intrinsically weak, Raman spectroscopy has become nowadays a routine method in many fields.[3]

Raman scattering is relies on inelastic scattering of monochromatic light, (usually from a laser in the visible, near infrared, or near ultraviolet range) by matter.

As in figure 1 the molecular system has two vibrational energy levels, the ground state and the excited state which are separated by the energy $h v_{M}$, where $v_{M}$ is the frequency of the molecular vibration. The incident light with energy $h v_{L}$ induces transitions to virtual levels. Returning to the initial state takes place in three different ways, namely by emitting light of frequencies $v_{L}, v_{L}-v_{K}$, and $v_{L}+v_{N}$. Rayleigh scattering arises from a transition that starts and finishes at the same vibrational energy level. The shifts to lower frequency called Stokes and higher frequency called as anti-Stokes Raman scattering. Stokes Raman scattering arises from a transition that starts at the ground state 
vibrational energy level and finishes at a higher vibrational energy level, whereas anti-Stokes Raman scattering involves a transition from a higher to a lower vibrational energy level. The anti-Stokes transitions are less likely to occur than the Stokes transitions, resulting in the Stokes Raman scattering being more intense. The intensity of Raman scattering is proportional to the square of the change in the molecular polarizability $\alpha$ resulting from a normal mode q: [4].

$$
I_{R A \propto(}\left(\frac{\partial \alpha}{\partial q}\right)
$$

Otherwise stated, a vibrational mode that satisfies the requirement

$$
\left(\frac{\partial \alpha}{\partial q}\right) \neq 0
$$

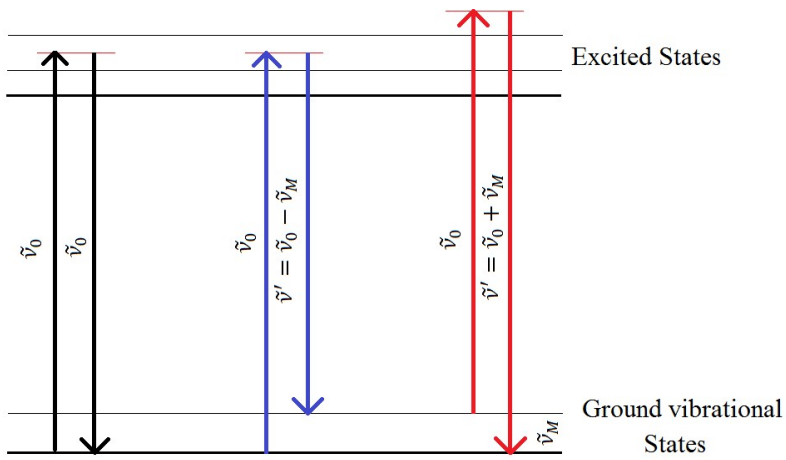

$$
\begin{gathered}
\text { Rayleigh Stokes Raman Anti-Stokes } \\
\text { Raman }
\end{gathered}
$$

Figure 1: The diagram the energy diagram of a molecule showing the Raman scattering.

Over the last decade, Raman spectroscopy has gained more and more interest in research as well as in identification and characterization of materials. As a vibrational spectroscopy technique, it is complementary to the also well-established infrared spectroscopy. Through specific spectral patterns, substances can be identified and molecular changes can be observed with high specificity.[5]

\section{Materials and Methods \\ I. Materials}

Five samples of Surface water were collected from water treatment plant from different regions in northern Sudan (Abohamd, Abry, Atbra, Halfa, and Shandy). Each sample was put in the glass substrate of the spectrometer and Raman spectrum was recorded in the region from 300 to 2800 $\mathrm{cm}^{-1}$. The Raman shift in wavenumber, and the change in intensities of the scattered light in Raman spectra were compared with data in the previous studies and references. The map below shows the areas which samples were taken from.

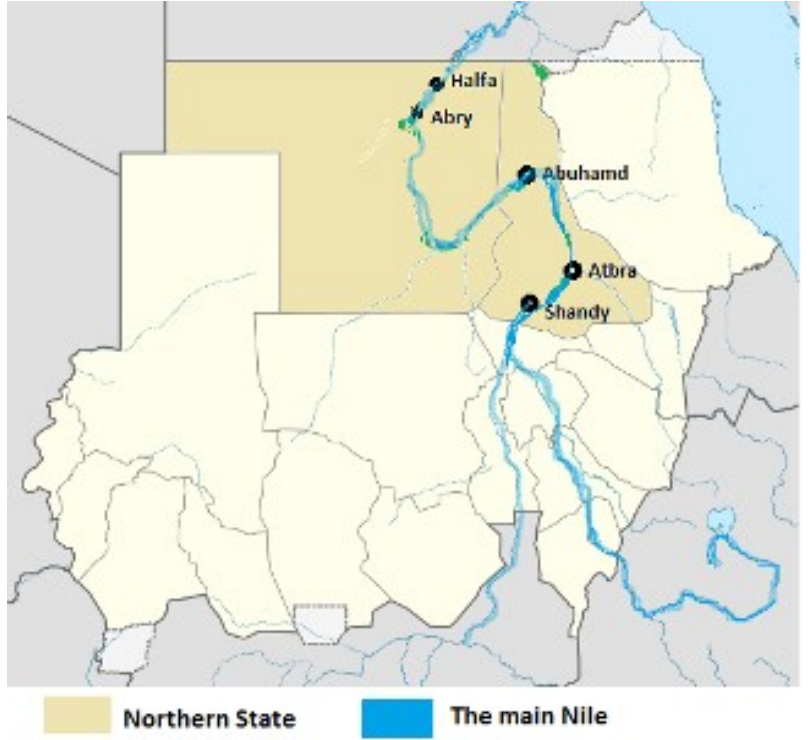

The map of areas which samples were taken from

\section{Instrumentation}

Laser Raman microscope spectrometer model Horiba Lab RAM HR D3, shown in the Figure 2 was used. The light source of this spectrometer is Nd-YAG laser with wavelength of $532 \mathrm{~nm}$ and output power of $6 \mathrm{~mW}$.

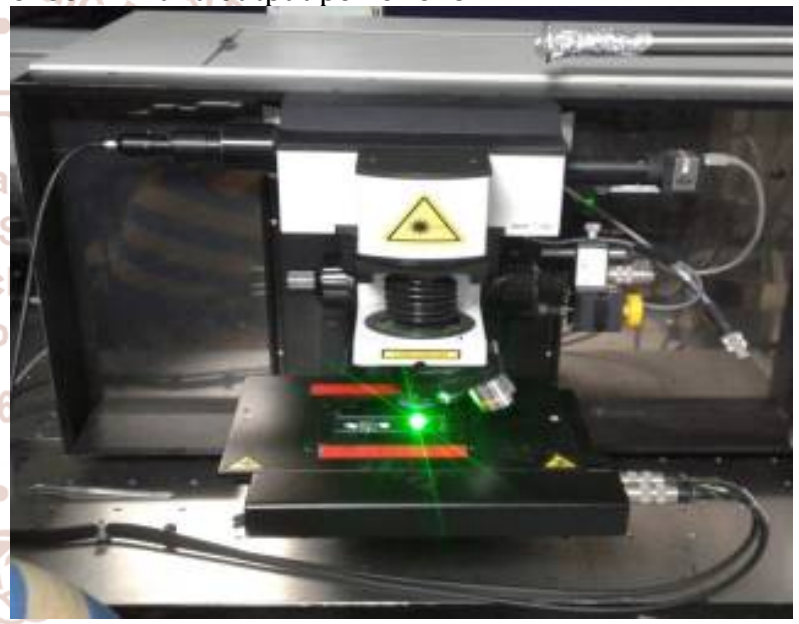

Figure2: Laser Raman spectrometer model Horiba Lab RAM 3D

\section{Results and discussion}

Figure 3 shows the Raman spectrum of a sample which taken from the water treatment plant in the area of Abohamd in the range from 456 to $2630 \mathrm{~cm}^{-1}$. Clear peaks were observed and by comparison with the vibrations recorded in previous studies and some references, we found that these vibrations describe the vibrations of water molecules and some components of other materials as listed in Table 1.

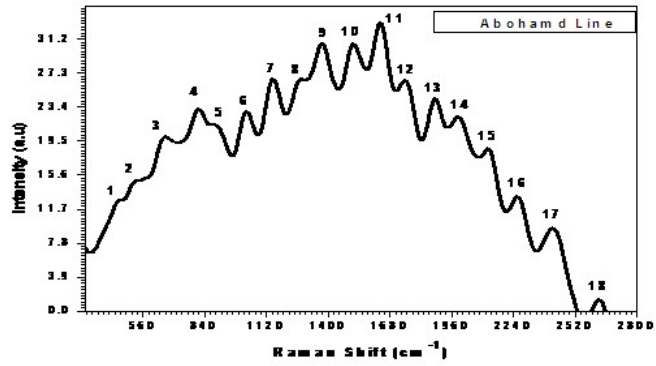

Figure 3: Raman spectrum of water sample taken from Abohamd in the range from 456 to $2630 \mathrm{~cm}^{-1}$. 
International Journal of Trend in Scientific Research and Development (IJTSRD) @ www.ijtsrd.com eISSN: 2456-6470

Table1: water sample collected from Abohamd water treatment plant

\begin{tabular}{|c|c|c|c|c|}
\hline Peak number & Peak Wavenumber CM & Intensity a.u & Functional group & References \\
\hline 1 & 456 & 12.85 & Si-O-Si & {$[6,7,8,9]$} \\
\hline 2 & 538 & 15.07 & Si-O-Si & {$[7,8,9,14]$} \\
\hline 3 & 660 & 20.12 & FeIII-O & {$[10]$} \\
\hline 4 & 810 & 23.37 & $v(\mathrm{C}-\mathrm{C})$ stretching vibration & {$[11]$} \\
\hline 5 & 891.7 & 21.50 & UO $_{2}^{+2}$ antisymmetric Stretching & {$[24]$} \\
\hline 6 & 1030 & 23.03 & $\delta(\mathrm{C}-\mathrm{H}) \delta$ : bending mode & {$[12]$} \\
\hline 7 & 1152 & 26.80 & Toluene & {$[13]$} \\
\hline 8 & 1270 & 26.72 & V(C-B $) \beta$ & {$[19]$} \\
\hline 9 & 1374.1 & 30.91 & Ethylbenzene & {$[13]$} \\
\hline 10 & 1510.9 & 30.83 & C C & {$[7,9,14,15]$} \\
\hline 11 & 1635 & 33.22 & O-H bending & {$[16]$} \\
\hline 12 & 1752 & 26.55 & Lactone & {$[7,14]$} \\
\hline 13 & 1876 & 24.48 & C=O stretching & {$[20]$} \\
\hline 14 & 1990 & 22.43 & - & - \\
\hline 15 & 2121.3 & 18.76 & Isothiocyanate & {$[7,14]$} \\
\hline 16 & 2262 & 13.27 & Diazonium salt & {$[7,14]$} \\
\hline 17 & 2411.6 & 9.60 & P - H & {$[7,14]$} \\
\hline 18 & 2630 & 1.47 & - & - \\
\hline
\end{tabular}

The Raman spectrum of a sample which taken from the water treatment plant in the area of Abry in the range from 481 to 2436 $\mathrm{cm}^{-1}$ as shown in figure 4 beside the vibrations of water molecules some other vibrations were appeared in the spectrum. As shown in Table 2.

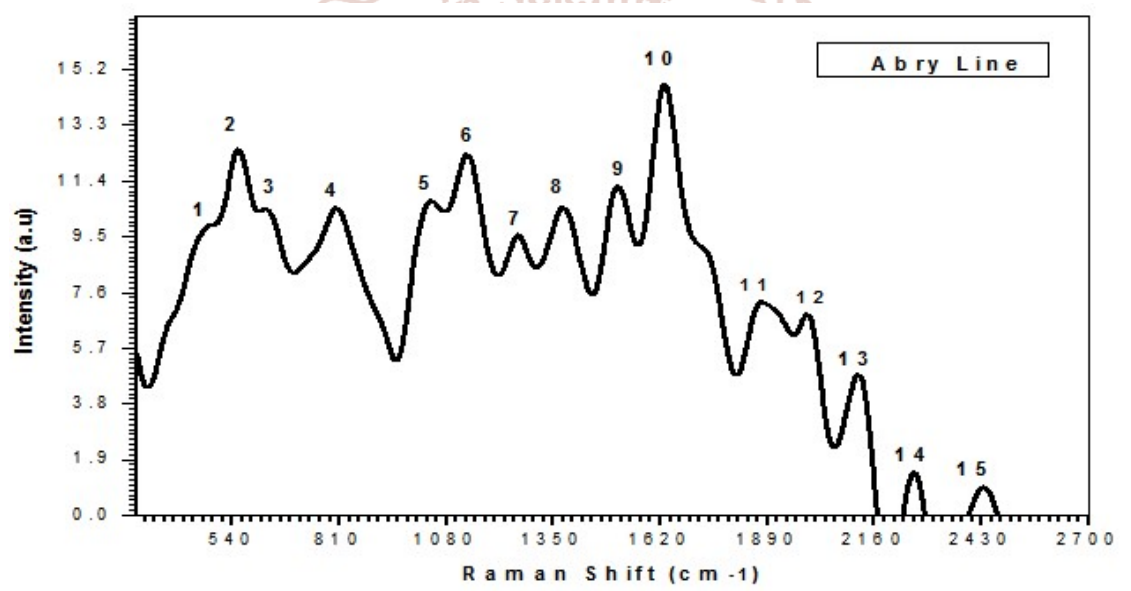

Figure 4: Raman spectrum of water sample taken from Abry in the range from 481 to $2436 \mathrm{~cm}^{-1}$.

Table2: water sample collected from Abry water treatment plant

\begin{tabular}{|c|c|c|l|c|}
\hline $\begin{array}{c}\text { Peak } \\
\text { number }\end{array}$ & Peak Wavenumber CM-1 & Intensity a.u & \multicolumn{1}{c|}{ Functional group } & $\begin{array}{c}\text { Reference } \\
\text { s }\end{array}$ \\
\hline 1 & 481 & 9.94 & - & - \\
\hline 2 & 545 & 12.56 & $\mathrm{Si}-$ - Si & {$[8,9]$} \\
\hline 3 & 625.1 & 10.48 & $\mathrm{C}=\mathrm{S}$ & {$[7,14]$} \\
\hline 4 & 810 & 10.56 & $v$ C-C) stretching vibration & {$[11]$} \\
\hline 5 & 1041.3 & 10.81 & Sulfonic acid & {$[7,14]$} \\
\hline 6 & 1136 & 12.39 & V3symmetric stretching of the per chlorate ion & {$[21]$} \\
\hline 7 & 1257 & 9.61 & C-O & {$[16]$} \\
\hline 8 & 1374.1 & 10.56 & Ethylbenzene & {$[13]$} \\
\hline 9 & 1510.9 & 11.27 & C = C & {$[7,9,14,15]$} \\
\hline 10 & 1635 & 14.76 & O-H bending & {$[16]$} \\
\hline 11 & 1877 & 7.32 & NO & {$[17]$} \\
\hline 12 & 1988 & 6.91 & - & - \\
\hline 13 & 2121.3 & 4.87 & Isothiocyanate & {$[7,14]$} \\
\hline 14 & 2262 & 1.55 & Diazonium salt & {$[7,14]$} \\
\hline 15 & 2436 & 1.00 & - & - \\
\hline
\end{tabular}

Figure 5 illustrates Raman spectrum of the water collected from the water treatment plant in the area of Atbra in the range from 389 to $2403 \mathrm{~cm}^{-1}$. Table 3 lists the analysis of this spectrum. 


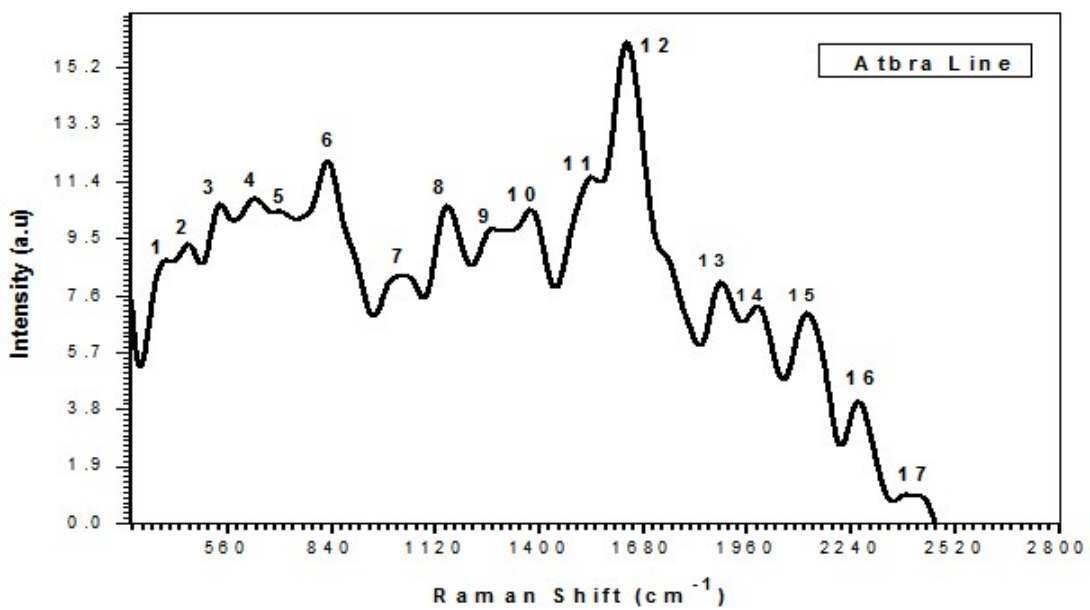

Figure 5: Raman spectrum of water sample taken from Atbra in the range from 389 to $2403 \mathrm{~cm}^{-1}$.

Table 3: water sample collected from Atbra water treatment plant

\begin{tabular}{|c|c|c|c|c|}
\hline Peak number & Peak Wavenumber cm-1 & Intensity a.u & Functional group & References \\
\hline 1 & 389 & 8.86 & $\alpha$ Fe-OH & {$[10,23]$} \\
\hline 2 & 456 & 9.40 & Si-O-Si & {$[6,7,8,9]$} \\
\hline 3 & 538 & 9.60 & Si-O-Si & {$[7,8,9,14]$} \\
\hline 4 & 635 & 10.90 & Acetylene C-H bending & {$[22]$} \\
\hline 5 & 704 & 10.48 & CaCO3 & {$[18]$} \\
\hline 6 & 840 & 12.19 & As-0 asymmetric vibration & {$[22]$} \\
\hline 7 & 1030 & 8.32 & $\delta(\mathrm{C}-\mathrm{H}) \delta$ : bending mode & {$[2]$} \\
\hline 8 & 1152 & 10.65 & Toluene & {$[13]$} \\
\hline 9 & 1270 & 9.90 & V(C-N) $\beta$ & {$[19]$} \\
\hline 10 & 1377 & 10.53 & Toluene & {$[13]$} \\
\hline 11 & 1535 & 11.60 & amide II & {$[20]$} \\
\hline 12 & 1635 & 16.14 & O-H bending & {$[16]$} \\
\hline 13 & 1899.4 & 8.11 & C = C & {$[7,9,14,15]$} \\
\hline 14 & 1984 & 7.32 & - & {[} \\
\hline 15 & 2121.3 & 7.08 & Isothiocyanate & {$[7,14]$} \\
\hline 16 & 2262 & 4.16 & Diazonium salt & {$[7,14]$} \\
\hline 17 & 2403 & 1.05 & P-H & {$[7,14]$} \\
\hline
\end{tabular}

The Raman spectrum of a sample taken from collected from the water treatment plant in the area of Halfa in the range from 389 to $2432 \mathrm{~cm}^{1}$ as figure 6 shows. it shows clear peaks and by comparison with the vibrations recorded in some references, we found that these vibrations describe the vibrations of water molecules and some components of other materials as listed in Table 4.

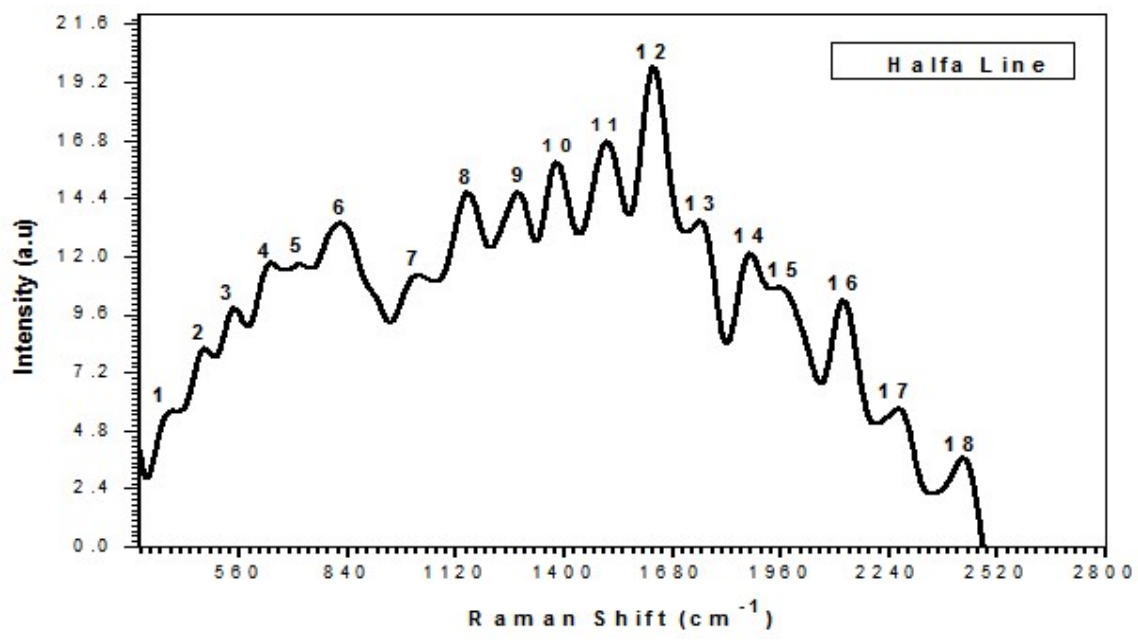

Figure 6: Raman spectrum of water sample taken from Halfa in the range from 389 to $2432 \mathrm{~cm}^{-1}$. 
International Journal of Trend in Scientific Research and Development (IJTSRD) @ www.ijtsrd.com eISSN: 2456-6470

Table4: water sample collected from Halfa water treatment plant

\begin{tabular}{|c|c|c|c|c|}
\hline Peak number & Peak Wavenumber cm-1 & Intensity a.u & Functional group & References \\
\hline 1 & 389 & 5.71 & $\alpha$ Fe-OH & {$[10,23]$} \\
\hline 2 & 464 & 8.29 & Si-O-Si & {$[7,8,9,14]$} \\
\hline 3 & 545 & 9.97 & Si -0-Si & {$[8,9]$} \\
\hline 4 & 641 & 11.84 & C=S & {$[7,8,14]$} \\
\hline 5 & 717.2 & 11.79 & {$[13]$} \\
\hline 6 & 822 & 13.45 & $\left(\text { ASO }^{4}\right)^{-3}$ symmetric stretching & {$[24]$} \\
\hline 7 & 1026 & 11.30 & Toluene & {$[13]$} \\
\hline 8 & 1152 & 14.75 & Toluene & {$[13]$} \\
\hline 9 & 1270 & 14.75 & V(C-N) $\beta$ & {$[19]$} \\
\hline 10 & 1377 & 16.04 & Toluene & {$[13]$} \\
\hline 11 & 1510.9 & 16.84 & C $=$ C & {$[7,9,14,15]$} \\
\hline 12 & 1635 & 19.97 & O-H bending & {$[16]$} \\
\hline 13 & 1752.5 & 13.56 & Lactone & {$[7.14]$} \\
\hline 14 & 1877 & 12.23 & NO & {$[17]$} \\
\hline 15 & 1960 & 10.82 & - & {$[7.14]$} \\
\hline 16 & 2121.3 & 10.34 & Isothiocyanate & {$[7.14]$} \\
\hline 17 & 2262 & 5.82 & Diazonium salt & - \\
\hline 18 & 2432 & 3.77 & - & {[} \\
\hline
\end{tabular}

Figure 7 illustrates Raman spectrum of the a sample which collected from the water treatment plant in the area of area of Shandy in the range from 389 to $2411.6 \mathrm{~cm}^{-1}$. Table 5 lists the analysis of this spectrum.

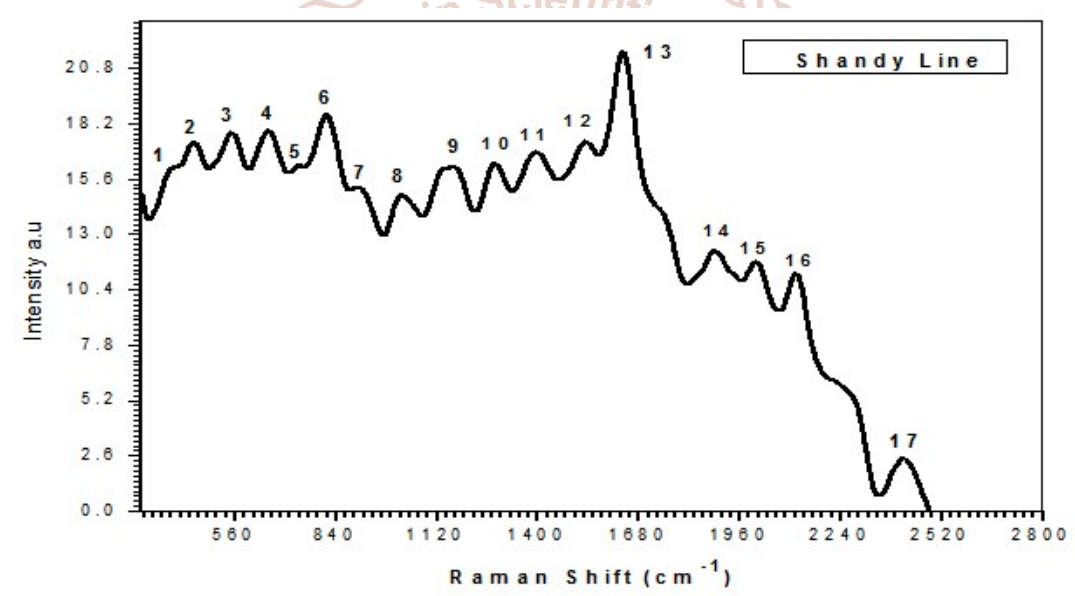

Figure7: Raman spectrum of water sample taken from Shandy in the range from 389 to $2411.6 \mathrm{~cm}^{-1}$.

Table5: water sample collected from Shandy water treatment plant

\begin{tabular}{|c|c|c|c|c|}
\hline Peak number & Peak Wavenumber cm-1 & Intensity a.u & Functional group & References \\
\hline 1 & 389 & 16.26 & $\alpha \mathrm{Fe}-\mathrm{OH}$ & {$[10,23]$} \\
\hline 2 & 448 & 17.44 & S-S & {$[7,8,9,14]$} \\
\hline 3 & 545 & 17.90 & $\mathrm{Si}-\mathrm{O}-\mathrm{Si}$ & {$[8,9]$} \\
\hline 4 & 650 & 18.01 & FeII-O & [25] \\
\hline 5 & 737 & 16.38 & - & - \\
\hline 6 & 810 & 18.74 & $v(\mathrm{C}-\mathrm{C})$ stretching vibration & [11] \\
\hline 7 & 891.7 & 15.31 & $\mathrm{UO}^{+2}{ }^{+2}$ antisymmetric Stretching & {$[24]$} \\
\hline 8 & 1026 & 14.97 & Toluene & [13] \\
\hline 9 & 1152 & 16.31 & Toluene & [13] \\
\hline 10 & 1270 & 16.43 & $\mathrm{~V}(\mathrm{C}-\mathrm{N}) \beta$ & [19] \\
\hline 11 & 1396.6 & 16.94 & Aromatic azo & {$[7,14]$} \\
\hline 12 & 1535 & 17.44 & amide II & [20] \\
\hline 13 & 1635 & 21.72 & $\mathrm{O}-\mathrm{H}$ bending & [16] \\
\hline 14 & 1890 & 12.33 & - & - \\
\hline 15 & 2004 & 11.81 & - & - \\
\hline 16 & 2121.3 & 11.26 & Isothiocyanate & {$[7,14]$} \\
\hline 17 & 2221.5 & 6.20 & Aromatic nitrile & \\
\hline 18 & 2411.6 & 2.60 & $\mathrm{P}-\mathrm{H}$ & {$[7,14]$} \\
\hline
\end{tabular}


International Journal of Trend in Scientific Research and Development (IJTSRD) @ www.ijtsrd.com eISSN: 2456-6470

\begin{abstract}
After analysis, it was found that, surface water samples contaminated by toxic substances with different concentrations such as follow:
\end{abstract}

In Abohamd region water contaminated by $\left(\mathrm{UO}_{2}{ }^{+2}, v(\mathrm{C}-\mathrm{N})_{\beta^{x}} \mathrm{P}-\mathrm{H}\right.$ and Ethylbenzene) with intensities $(21.50,26.72,9.60$ and 30.91$)$ respectively.

In Abry region water contaminated by (Ethylbenzene and NO) with intensities (10.56 and 7.32) respectively.

In Atbra region water contaminated by $\left(v(C-N)_{\beta}\right.$ and $\mathrm{P}-$ H) with intensities (9.90 and 1.05$)$ respectively.

In Halfa region water contaminated by $\left(\left(\mathrm{ASO}_{4}\right)^{-3}, v(\mathrm{C}-\mathrm{N})_{\mathrm{B}}\right.$ and NO) with intensities (13.45, 14.75 and 12.23 ) respectively.

In Shandy region water contaminated by $\left(\mathrm{S}-\mathrm{S}, \mathrm{UO}_{2}{ }^{+2}, \mathrm{P}-\mathrm{H}\right.$ and $\left.v(C-N)_{\beta}\right)$ with intensities $(17.44,15.31,2.60$ and 16.43) respectively.

cyanide is highly toxic. The cyanide anion is an inhibitor of the enzyme cytochrome c oxidase in the fourth complex of the electron transport chain (found in the membrane of the mitochondria of eukaryotic cells). It attaches to the iron within this protein. The binding of cyanide to this enzyme prevents transport of electrons from cytochrome $\mathrm{c}$ to oxygen. As a result, the electron transport chain is disrupted, meaning that the cell can no longer aerobically produce ATP for energy. Tissues that depend highly on aerobic respiration, such as the central nervous system and the heart, are particularly affected. This is an example of histotoxic hypoxia.

Nitrate poisoning can occur through enterohepatic metabolism of nitrate due to nitrite being an intermediate. Nitrites oxidize the iron atoms in hemoglobin from ferrous iron(II) to ferric iron(III), rendering it unable to carry oxygen. This process can lead to generalized lack of oxygen in organ tissue and a dangerous condition called methemoglobinemia. Although nitrite converts to ammonia, if there is more nitrite than can be converted, the animal slowly suffers from a lack of oxygen.

Arsenate can replace inorganic phosphate in the step of glycolysis that produces 1,3-bisphosphoglycerate from glyceraldehyde 3-phosphate. This yields 1-arseno-3phosphoglycerate instead, which is unstable and quickly hydrolyzes, forming the next intermediate in the pathway, 3phosphoglycerate. Therefore, glycolysis proceeds, but the ATP molecule that would be generated from 1,3bisphosphoglycerate is lost - arsenate is an uncoupler of glycolysis, explaining its toxicity.

\section{Conclusion}

Raman spectroscopy is a powerful tool that allows to carry out an accurate quantitative analysis of concentrations of species present in the surface water. Accordingly, we recommend the Ministry of Water and Irrigation in Sudan to improve the work and efficiency of drinking water treatment plants in Northern Sudan, as well as increase the number of water treatment plants.

\section{Acknowledgements}

We wish to thank the Institute of Laser in Sudan for supporting this research and Indian Institute of Science for recording the Raman spectra .

\section{References}

[1] Gertsen, N. and Sønderby, L., 2009. Water Purification. Nova Science Publishers.

[2] Khetan, S.K. and Collins, T.J., 2007. Human pharmaceuticals in the aquatic environment: a challenge to green chemistry. Chemical reviews, 107(6), pp.2319-2364.

[3] Marek Procházka, 2016. Surface-Enhanced Raman Spectroscopy Bioanalytical, Biomolecular and Medical Applications, Institute of Physics, Charles University in Prague, Prague 2, Czech Republic.

[4] Tu, A.T., 1982. Raman spectroscopy in biology. Principles and Applications, 1.

[5] Eberhardt, K., Stiebing, C., Matthäus, C., Schmitt, M. and Popp, J., 2015. Advantages and limitations of Raman spectroscopy for molecular diagnostics: an update. Expert review of molecular diagnostics, 15(6), pp.773787.

[6] Ferraro, J.R., Nakamoto, K. and Brown, C.W., 2003. Introductory Raman Spectroscopy 2nd edn (San Diego, CA: Academic).

[7] Robert, M.S., Francis, X.W. and David, J.K., 2005. Spectrometric identification of organic compounds. John wiley \& Sons, Inc, Hoboken, edn, 7, p.106.

[8] MANOHARAN, R. and SETHI, N., 2003. 8.51 Raman Analyzers.

[9] Socrates, G., 2004. Infrared and Raman characteristic group frequencies: tables and charts. John Wiley \& Sons.

[10] Oh, S.J., Cook, D.C. and Townsend, H.E., 1998. Characterization of iron oxides commonly formed as corrosion products on steel. Hyperfine interactions, 112(1-4), pp.59-66.

[11] De Veij, M., Vandenabeele, P., De Beer, T., Remon, J.P. and Moens, L., 2009. Reference database of Raman spectra of pharmaceutical excipients. Journal of Raman Spectroscopy: An International Journal for Original Work in all Aspects of Raman Spectroscopy, Including Higher Order Processes, and also Brillouin and Rayleigh Scattering, 40(3), pp.297-307.

[12] Başar, G., Parlatan, U., Şeninak, Ş., Günel, T., Benian, A. and Kalelioğlu, İ., 2012. Investigation of preeclampsia using raman spectroscopy. Journal of Spectroscopy, 27(4), pp.239-252.

[13] Li, G., Chen, M. and Wei, T., 2009, July. Application of Raman spectroscopy to detecting organic contaminant in water. In 2009 IITA International Conference on Control, Automation and Systems Engineering (case 2009) (pp. 493-495). IEEE.

[14] Edwards HG., 2005. Modern Raman spectroscopy-a practical approach. Ewen Smith and Geoffrey Dent. John Wiley and Sons Ltd, Chichester, Pp. 210. ISBN 0 471496685 (cloth, hb); 0471497940 (pbk). 
International Journal of Trend in Scientific Research and Development (IJTSRD) @ www.ijtsrd.com eISSN: 2456-6470

[15] Lin-Vien, D., Colthup, N.B., Fateley, W.G. and Grasselli, J.G., 1991. The handbook of infrared and Raman characteristic frequencies of organic molecules. Elsevier.

[16] Durickovic, I. and Marchetti, M., 2014. Raman spectroscopy as polyvalent alternative for water pollution detection. IET Science, Measurement \& Technology, 8(3), pp.122-128.

[17] Gang Li, Guoping Zhang, 2006. Laser Raman spectroscopy in water analysis, Advanced Laser Technologies, edited by Ivan A. Shcherbakov, Kexin Xu, Qingyue Wang, Alexander V. Priezzhev, Vladimir I. Pustovoy, Proc. of SPIE Vol. 6344, 63441J.

[18] Seok Chan Park, Minjung Kim and et al., 2009. Wide area illumination Raman scheme for simple and nondestructive discrimination of seawater, journal of Raman spectroscopy.

[19] Ćirić-Marjanović, G., Trchová, M. and Stejskal, J., 2008. The chemical oxidative polymerization of aniline in water: Raman spectroscopy. Journal of Raman Spectroscopy: An International Journal for Original Work in all Aspects of Raman Spectroscopy, Including Higher Order Processes, and also Brillouin and Rayleigh Scattering, 39(10), pp.1375-1387.

[20] Phongpa-Ngan, P., Aggrey, S.E., Mulligan, J.H. and Wicker, L., 2014. Raman spectroscopy to assess water holding capacity in muscle from fast and slow growing broilers. LWT-Food Science and Technology, 57(2), pp.696-700.

[21] Sobrón, P., Rull, F., Sobron, F., Sanz, A., Medina, J. and Nielsen, C.J., 2007. Modeling the physico-chemistry of acid sulfate waters through Raman spectroscopy of the system FeSO4? H2SO4? H2O. Journal of Raman Spectroscopy: An International Journal for Original Work in all Aspects of Raman Spectroscopy, Including Higher Order Processes, and also Brillouin and Rayleigh Scattering, 38(9), pp.1127-1132.

[22] X. Song et al., 2013. Detection of herbicides in drinking water by surface-enhanced Raman spectroscopy coupled with gold nanostructures, Food Measure (2013) 7:107-113 DOI 10.1007/s11694-013-9145-4.

[23] Cornell, R.M. and Schwertmann, U., 2003. The iron oxides: structure, properties, reactions, occurrences and uses. John Wiley \& Sons.

[24] Frost, R.L., Weier, M.L., Čejka, J. and Theo Kloprogge, J., 2006. Raman spectroscopy of walpurgite. Journal of Raman Spectroscopy: An International Journal for Original Work in all Aspects of Raman Spectroscopy, Including Higher Order Processes, and also Brillouin and Rayleigh Scattering, 37(5), pp.585-590.

[25] Nafie A. Almusleta, Mubarak M. Ahmedb, Siham M. Hassenc, 2016. Characterization of Magnetite and 2line Ferrihydrite Using Laser Raman Spectroscopy International Journal of Sciences: Basic and Applied Research (IJSBAR).

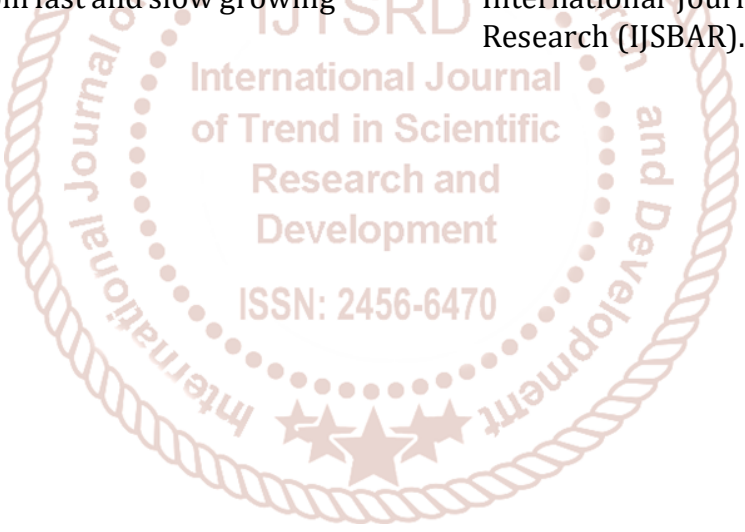

